\title{
Criminal Investigation of Motorcycle Stealing Goods
}

\author{
Yusril Ilza Amri*), Bambang Tri Bawono**) and Ira Alia Maerani**) \\ *) Student of Master of Law, Universitas Islam Sultan Agung Semarang, E-mail: \\ yusrililzaa@gmail.com \\ $\left.{ }^{* *}\right)$ Lecturer of Master of Law, Universitas Islam Sultan Agung Semarang \\ ${ }^{* * *)}$ Lecturer of Master of Law, Universitas Islam Sultan Agung Semarang
}

\begin{abstract}
.
This study aims to identify and analyze the factors that cause the increase in the number of criminal acts of arresting the results of motorcycle theft in the jurisdiction system of the Pati Regency Resort, as well as to identify and analyze the investigative actions carried out by the Pati Regency Police in the conception of law enforcement. This study uses a juridical empirical (sociological) approach. The results showed that there was an increase in criminal acts of detention of the results of motor vehicle theft in the jurisdiction of the Pati Police, including the desire to own a motorized vehicle, the economic condition of the perpetrator, the perpetrator's friendship, low legal knowledge, the intention to help the perpetrator of theft, persuade and lure profits, and in cooperation with many parties. Then the investigation carried out by the Pati Police on the criminal act of arresting a motor vehicle resulting from theft through 4 (four) stages, including: receipt of reports, summons, confiscation, and investigation. The obstacles faced by the Pati Resort Police included: the perpetrator moved from place to place, the perpetrator lost evidence, the lack of public participation, and the difficulty of proving it. Efforts made by the Pati Resort Police include 3 (three) attempts. Preemptive efforts are carried out by providing legal counseling to the public regarding criminal acts of theft and detention. Preventive measures are carried out by conducting raids and patrolling locations deemed prone to theft. The last resort.
\end{abstract}

Keywords: Crime; Detention; Theft; Motorcycle.

\section{Introduction}

Acting against the law is a disgraceful act or commonly called a crime, especially a violation of criminal law. Criminal law or in Dutch is called strafrecht, which means a whole set of rules regarding violations and crimes against the public interest, which act is punishable by suffering. What is meant by suffering is in the form of a bad taste or sorrow. Or it can also be stated that criminal law is a law that contains regulations that contain compulsions or prohibitions against violations which are punishable by bodily torture. ${ }^{1}$

Crime can be interpreted criminologically and juridically. Crime in a criminological sense is human action that tarnishes the basic norms of society. This is intended as an act of elements that violate the rules that live and develop in society. Juridical crime, namely evil behavior or evil deeds in the meaning of criminal law means that the crime is formulated in criminal regulations. One example of a crime is the criminal act of detention as stipulated in Article 480 to Article 485 of the Criminal Code.

\footnotetext{
${ }^{1}$ Ibid, p. 87
} 
Police officers are given the responsibility primarily to maintain public order and handle criminal acts, planning or crime prevention policies as outlined in the Legislation include: Planning or policies regarding actions that are prohibited because what they discuss is considered dangerous or detrimental, as well as planning or policies regarding what sanctions will be imposed against the perpetrator of the prohibited act (whether criminal or act) and the implementation of the system. ${ }^{2}$

In a narrow sense, in the sense of the subject, that law enforcement officers only become interpreted as certain law enforcement efforts to guarantee and ensure that the rule of law is as it should be. ${ }^{3}$

The practice of detaining the results of motorbike theft in Pati Regency is rampant, this is actually caused by the culture of the Pati people who do not want to take the hassle and face of law enforcement in traffic can still be compromised in the end to buy an incomplete motorbike, due to high community demand, then make the thief able to communicate the stolen goods to be able to be sold by third parties called custodians.

Based on the description of the background described above, the following problems are formulated: What factors cause the increase in the number of criminal offenses resulting from motorbike theft in the jurisdictional legal system? How are the investigative actions carried out by the Police in the conception of law enforcement?

\section{Research Methods}

The approach method used in this research is a sociological juridical approach. The specification that will be used in this research is descriptive research. Sources of data used in this study include primary data and secondary data. Data collection techniques used in this research are literature and field studies. The data analysis technique used in this research is a qualitative analysis technique.

\section{Results and Discussion}

\subsection{Based on the records of territorial jurisdiction}

In terms of the location of the teaching incident where the tools and teachings worked, the result was theft which led to detention in Pati. Meanwhile, based on the person location approach, this case will result in 2 (two) different places. If viewed from the location of the perpetrator (active personal), the jurisdiction will prevail. However, if it is viewed from the location of the victim (active personal), the jurisdiction will prevail. An increase in criminal acts of detention of proceeds from motor vehicle theft includes, among others:

\footnotetext{
2 Dwi Fahri Hidayatullah, Gunarto Gunarto, Lathifah Hanim, "Police Role in Crime Investigation of Fencing Article 480 of the Criminal Code (Study in Polres Demak)" Jurnal Daulat Hukum Vol 2, No 4 (2019): December 2019 url: http://jurnal.unissula.ac.id/index.php/RH/article/view/8288/3864 3 Ibid.
} 
- The desire to own a motorized vehicle is one of the factors in the occurrence of catching the results of the curanmor.

- The economic condition of the perpetrator, the crime is inseparable from the ongoing socio-economic conditions and accommodates behavioral forms of community members.

- The friendship of the perpetrators, the friendship of the perpetrators of detention is one of the opportunities for them to commit crimes.

- Low legal knowledge, legal awareness is the way people perceive the law itself.

- The intention of helping the perpetrator of theft, committing theft and stolen goods is given to his friend with the intention of helping his friend to sell the proceeds of the crime.

- Cajoling and being lured of profit

- In cooperation with many parties, the perpetrators of this detention work together by asking people around the person who wants to sell the proceeds of theft.

Soerjono Soekanto argues that motor vehicle theft is a crime against property that is not common in developing countries. As stated in the category, motorized vehicles are a means of transportation with high mobility. ${ }^{4}$ Andi Hamzah is of the opinion that the criminal act of detention is called a criminal offense, that is, because the act of stifling has encouraged others to commit crimes that might not have been committed if no one was willing to accept the proceeds of the crime. ${ }^{5}$ So it can be concluded that the more prevalent cases of motor vehicle theft, the more criminal acts of detention of motor vehicles resulting from the theft.

The factors causing the crime of proceeds theft are due to internal and external factors;

- Internal factors: Mental factors or intelligence; Mental factors relate to level intelligence. If someone has a good level of intelligence, of course it is people can easily adapt to the circumstances and development of society. On the other hand, if the level of intelligence is low, then the person concerned will not be able to find and find the best way and is no exception to taking actions that are deviant and contrary to the prevailing laws.

- External Factors: 1) Environmental Factors: if the social environment in the community where he lives is an environment where the perpetrator of the crime is not impossible then he will be carried away by committing a crime. One of the reasons for a person to commit a criminal act is the condition of the environment in which that person is located. A person cannot be a criminal only from a poor family, but also from a rich family. In general, people who are committed. ${ }^{6}$

If we find that the criminal act of detention and the crime of theft is a different or separate offense which is regulated in different articles, the elements of the crime are also different, so even though the criminal act of detaining the

\footnotetext{
${ }^{4}$ Soerjono Soekanto, et al. (1988). Penanggulangan Pencurian Kendaraan Bermotor Suatu Tinjauan Kriminologi. Jakarta: Aksara. p. 20

${ }^{5}$ Andi Hamzah. (2009). Delik-Delik Tertentu di Dalam KUHP. Jakarta: Sinar Grafika. p. 11

6 Supriyono, Criminology Study Of Crime Of Fencing The Stolen Goods, Jurnal daulat Hukum, vol 3 No 1 (2020) March 2020, http://jurnal.unissula.ac.id/index.php/RH/article/view/8407/4068
} 
motorbike the thief is not known, the case file can be declared complete. by the Public Prosecutor regarding his detention. Indeed, it is better if the thief is known to make it easier to prove it in court examination, although this is not absolute.

The causes of motor vehicle theft are influenced by several factors, including economic factors, environmental factors, educational factors, law enforcement factors, individual factors and global development factors. ${ }^{7}$ Apart from that, the owner's negligence, such as not using double locks and the existence of a container to accommodate the crime of theft, making it easier for the perpetrator to immediately make a profit, so that the perpetrator does not have to sell the stolen goods to the buyer himself. 8

Moch. Anwar is of the opinion that in a criminal act/criminal act of detention, there are 2 (two) crimes that are regulated, namely: ${ }^{9}$

- Detention that facilitates other crimes, is simply about the holding of goods obtained from other crimes that have been determined.

- Printing crime which facilitates crime which consists of insulting and sedition.

\subsection{The investigation by the Police on the criminal act}

To detaining a vehicle resulting from theft through 4 (four) stages includes: receipt of reports, summons, confiscation and investigation. The obstacles faced by the Pati Resort Police included: the perpetrator moved from place to place, the perpetrator lost evidence, the lack of public participation, and the difficulty of proving it. Efforts made by the Pati Resort Police include 3 (three) efforts, namely pre-emptive efforts, preventive efforts, and repressive measures. Pre-emptive efforts are carried out by providing legal counseling to the public regarding criminal acts of theft and detention. Preventive measures are carried out by conducting raids and patrolling locations deemed prone to theft. The last resort.

The statement above was reinforced by one of the incidents of theft and detention of motor vehicles that occurred during the 2020 Candi Jaran Brush Operation at the Semarang Police Headquarters. During the press conference, the Semarang Police Chief said that 2 motorbikes and 3 cars were confiscated. The police chief stated that all the evidence for curanmor came from the Pati district. ${ }^{10}$

The above description also shows that the criminal act of embezzlement that has ended in the current motor vehicle arrest is something that has never been expected and will not be ignored by people anywhere. The community, together with the government, through its law enforcement officers, will always try to tackle crime or at least reduce the number of crimes.

\footnotetext{
${ }^{7}$ Berdy Despar Magrhobi. (2014). Tinjauan Kriminologis Faktor Penyebab Terjadinya Tindak Pidana Pencurian Kendaraan Bermotor (Studi di Lembaga Pemasyarakatan Lowokwaru Malang), Jurnal Mahasiswa Fakultas Hukum Universitas Brawijaya: p.16

8 M. Kholil.( 2018). Tinjauan Empiris Pasal 480 KUHP Tentang Penadahan Menyangkut Hak-Hak Konsumen Dalam Pasal 4 Undang-Undang Nomor 8 Tahun 1999 Tentang Perlindungan Konsumen, Jurnal Hukum Bisnis Bonum Commune Vol 1 No 1.p.54

${ }^{9}$ A. A Ngurah Wirasila, dkk. (2017). Buku Ajar: Tindak Pidana Tertentu Dalam KUHP, Universitas Udayana. P. 96

10https://radarsemarang.jawapos.com/berita/semarang/2020/08/04/kasus-curanmorterbanyak-dari-w Wilayah-pati/, accessed on Thursday, 15 October 2020 at 16.00 WIB.
} 
Several attempts have also been made to uncover and dissect the problem of incarceration cases. The National Police, which is also an instrument of the state, plays a role in maintaining public security and order, upholding the law, and providing protection, protection and services to the community in the context of maintaining domestic security. The Police of the Republic of Indonesia are the National Police which are one unit in carrying out the role of maintaining security, maintaining public order, enforcing law and providing protection and protection as well as services to the community in the framework of maintaining domestic security.

In the criminalization process in the form of legal products that are created, it can be seen in the laws and regulations governing criminal acts regulated in the Criminal Code in Articles 480-482 with the form of detention as follows:

- Detention in the form of principle (Article 480 of the Criminal Code); Article 480 of the Criminal Code is regulated as follows: By imprisonment up to four years or a maximum fine of Rp. 900, - punished: Because as an accomplice, anyone who buys, rents, exchanges, accepts a pledge, receives a gift or gets a profit, keeps or hides an item, which he knows or should have obtained because it is a crime; Anyone who takes advantage of the results of something, knows or deserves it, must be assumed that it was obtained because of evil

- Detention as a habit (Article 481 of the Criminal Code); Article 481 of the Criminal Code is as follows: Anyone who makes a habit intentionally buying, exchanging, accepting a pledge, keeping or hiding objects, obtained for a crime, is sentenced to imprisonment of up to seven years; That the wrong person can be deprived of the rights mentioned in Article 35 No. 1-4 and may be fired from doing work that was used to commit a crime (KUHP 35, 480, 486, 517) .11 Light arrest (Article 482 KUHP);

- Article 482 of the Criminal Code is regulated as follows: The act described in Article 480 is subject to a light sentence, a maximum imprisonment of three months or a maximum fine of Rp. 900, -, if the item was obtained because of one of the crimes described in Articles 364, 373, 379.12 11

\section{Closing}

There has been an increase in cases of theft and detention of motor vehicles, namely because The desire to own a motorized vehicle, the perpetrator's economic condition, the perpetrator's friendship, low legal knowledge, the intention to help the perpetrator of theft, persuade and lure profits, cooperate with many parties. And for the investigation itself, the Police will share actions, namely receiving reports, summoning, confiscating and investigating. And for the obstacles faced by the Pati Resort Police, among others are: the perpetrator moved from place to place, the perpetrator lost evidence, lack of community participation, and the difficulty of proving it. Efforts made by the Pati Resort Police include 3 (three) efforts, namely pre-emptive efforts, preventive efforts, and repressive measures.

\footnotetext{
11 Supriyono, Criminology Study Of Crime Of Fencing The Stolen Goods, Jurnal daulat Hukum,vol 3 No 1 (2020) Maret 2020, http://jurnal.unissula.ac.id/index.php/RH/article/view/8407/4068.
} 
Pre-emptive efforts are carried out by providing legal counseling to the public regarding criminal acts of theft and detention.

People are urged to be more careful in buying motorized vehicles, not to be easily tempted by cheap prices. It is hoped that the Pati Resort Police will provide a legal approach in seeking information from the public so that it should be understood and implemented as well as possible so that the community is not afraid to provide information about suspected criminal acts of detention in the surrounding environment.

\section{References}

\section{Journals:}

[1] Dwi Fahri Hidayatullah, Gunarto Gunarto, Lathifah Hanim, "Police Role in Crime Investigation of Fencing Article 480 of the Criminal Code (Study in Polres Demak)" Jurnal Daulat Hukum Vol 2, No 4 (2019): December 2019 url: http://jurnal.unissula.ac.id/index.php/RH/article/view/8288/3864

[2] Supriyono, Criminology Study Of Crime Of Fencing The Stolen Goods, Jurnal daulat Hukum, vol 3 No 1 (2020) March 2020, http://jurnal.unissula.ac.id/index.php/RH/article/view/8407/4068

[3] M. Kholil.( 2018). Tinjauan Empiris Pasal 480 KUHP Tentang Penadahan Menyangkut Hak-Hak Konsumen Dalam Pasal 4 Undang-Undang Nomor 8 Tahun 1999 Tentang Perlindungan Konsumen, Jurnal Hukum Bisnis Bonum Commune Vol 1 No 1.

\section{Books:}

[1] A.A Ngurah Wirasila, dkk. (2017). Buku Ajar: Tindak Pidana Tertentu Dalam KUHP, Universitas Udayana.

[2] Andi Hamzah. (2009). Delik-Delik Tertentu di Dalam KUHP. Jakarta: Sinar Grafika.

[3] Berdy Despar Magrhobi. (2014). Tinjauan Kriminologis Faktor Penyebab Terjadinya Tindak Pidana Pencurian Kendaraan Bermotor (Studi di Lembaga Pemasyarakatan Lowokwaru Malang), Jurnal Mahasiswa Fakultas Hukum Universitas Brawijaya:

[4] Soerjono Soekanto, et al. (1988). Penanggulangan Pencurian Kendaraan Bermotor Suatu Tinjauan Kriminologi. Jakarta: Aksara.

\section{Internet:}

[1] https://radarsemarang.jawapos.com/berita/semarang/2020/08/04/kasuscuranmor-terbanyak-dari-w Kawasan-pati/. 